\title{
O RELATÓRIO COMO ELEMENTO ESSENCIAL DA DECISÃO JUDICIAL ${ }^{1}$
}

\section{THE REPORT AS AN ESSENTIAL ELEMENT OF THE JUDICIAL DECISION}

\section{Carlos Frederico Bastos Pereira}

Doutorando em Direito Processual pela Universidade de São

Paulo (USP). Mestre em Direito Processual pela Universidade Federal do Espírito Santo (UFES). Professor de Direito Processual Civil na Faculdade de Direito de Vitória (FDV). Advogado. Vitória/ES. E-mail: fredbastospereira@gmail.com

RESUMO: O artigo examina o relatório como elemento estruturante das decisões judiciais e conclui pela necessidade de valorizá-lo na sentença e nos julgamentos colegiados a partir de suas funções descritiva e preparatória, com o objetivo de tornar mais eficiente o controle da decisão judicial. Embora relevante, a falta do relatório ou o defeito na sua elaboração só gera a nulidade da decisão judicial se houver prejuízo. A metodologia utilizada foi revisão bibliográfica e jurisprudencial para realizar uma análise histórica e dogmática do relatório como elemento da decisão judicial.

PALAVRAS-CHAVE: Relatório. Decisão judicial. Sentença. Julgamentos colegiados. Direito Processual.

ABSTRACT: This paper examines the report as a structuring element of judicial decisions and concludes by the need to value it in judgments and bench decisions based on descriptive and preparatory functions, in order to make the control of the judicial decision more efficient. Although relevant, the lack of the report or the defect in its preparation only generates the nullity of the judicial decision if there is harm. The methodology used was a bibliographical and jurisprudential review to carry out a historical and dogmatic analysis of the report as an element of the court decision.

\footnotetext{
${ }^{1}$ Artigo recebido em 04/05/2021 e aprovado em 08/07/2021.
} 
KEYWORDS: Report. Judicial decision. Judgment. Bench decision. Procedural law.

SUMÁRIO: 1. Introdução; 2. Elementos da decisão judicial; 3. Funções do relatório; 4. O relatório nas sentenças; 5. O relatório nos julgamentos colegiados; 6. Embargos de declaração como meio de controle do relatório; 7. Conclusões. Referências.

\section{INTRODUÇÃO}

Para julgar, juízes e Tribunais devem contextualizar o caso em que será proferida a decisão e apresentar as questões de fato e de direito que serão analisadas. Essa tarefa cabe ao relatório, como um dos elementos estruturantes do ato decisório.

Embora muitas linhas tenham sido escritas sobre a fundamentação e o dispositivo, pode-se dizer que a relevância do relatório é menosprezada. É conhecida, por exemplo, a dispensa do relatório nas sentenças proferidas em Juizados Especiais (art. 38, Lei n. ${ }^{\circ}$ 9.099/1995).

O presente artigo busca resgatar a importância do papel desempenhado pelo relatório na construção da decisão judicial, demonstrando como a sua valorização pode conferir mais qualidade à prestação da tutela jurisdicional.

Em primeiro lugar, analisará a evolução histórica dos elementos da decisão judicial (relatório, fundamentação e dispositivo) no CPC de 1939, de 1973 e de 2015; em segundo lugar, examinará as funções descritiva e preparatória do relatório; em terceiro lugar, debaterá aspectos do relatório nas sentenças; em quarto lugar, discutirá particularidades do relatório nos julgamentos colegiados; por fim, em quinto lugar, demonstrará como os embargos de declaração consistem no canal adequado para exercer o controle judicial de decisões que não possuem relatório e de decisões que possuem relatórios realizados de forma defeituosa.

A elaboração do trabalho buscou realizar uma análise histórica e dogmática do relatório nas sentenças e no julgamento colegiado mediante uma revisão bibliográfica e jurisprudencial do tema. 
Ao final, chegou-se à conclusão de que o relatório desempenha um papel importante na construção das decisões judiciais a partir das suas funções descritiva e preparatória, promovendo, via de consequência, uma série de normas fundamentais do processo civil brasileiro como eficiência, cooperação, contraditório e dever de fundamentação.

\section{ELEMENTOS DA DECISÃO JUDICIAL}

Toda decisão judicial deve dizer o que está decidindo, por que está decidindo e o que decidiu. Buscando expressar esse raciocínio, os Códigos de Processo Civil brasileiros, historicamente, estabeleceram como deve ser a estrutura mínima de um ato decisório. Em todos os três, a estrutura delimitada sempre foi a mesma: relatório, fundamentação e conclusão (dispositivo).

O CPC/1939, no art. 280, previa que a sentença conterá relatório, os fundamentos de fato e de direito e a decisão. No parágrafo único, foi especificado que "o relatório mencionará o nome das partes, o pedido, a defesa e o resumo dos respectivos fundamentos". O texto valia-se do verbo conter, representado pelo substantivo conteúdo. Bem-vistas as coisas, o conteúdo da sentença corresponde à norma jurídica individual e concreta estabelecida para julgamento do caso ${ }^{2}$. Isto é, o preceito que declara a existência, a inexistência ou o modo de ser de uma relação jurídica; que constitui situações jurídicas, alterando-as, criando-as ou extinguindo-as; ou que condena a uma prestação. Assim, é inevitável concluir que relatório, fundamentação e decisão não representam o conteúdo da sentença.

O CPC/1973, com o art. 458, passou a descrever os "requisitos essenciais da sentença" ${ }^{3}$ e a denominação foi alterada para mencionar os termos relatório, fundamentação e dispositivo. As mudanças não passaram despercebidas pela doutrina, que passou a criticar a utilização do termo "requisitos". Dizia-se que "os requisitos são

\footnotetext{
${ }^{2}$ Sobre a definição do conteúdo da sentença, diferenciando-o dos efeitos por ela produzidos, cfr. BARBOSA MOREIRA, José Carlos. Conteúdo e efeitos da sentença: variações sobre o tema. In: Temas de direito processual: quarta série. São Paulo: Saraiva, 1989, p. 175-183.

${ }^{3}$ À época, a alteração recebeu elogios da doutrina, na medida em que "o emprego do vocábulo requisito, pois, dá mais expressividade ao texto da disposição comentada; trata-se da exigência que o juiz (ou tribunal) há de necessariamente atender por ser essencial" (ARAGÃO, Egas Dirceu Moniz de. Sentença e coisa julgada: exegese do Código de Processo Civil (arts. 444 a 475). Rio de Janeiro: Aide, 1992, p. 97).
} 
expressos mediante adjetivos, são qualidades, atributos" e que uma alteração alvissareira seria substitui-la por "elementos", já que, na verdade, constituem "partes que devem integrar a estrutura da sentença"4. No inciso I do dispositivo ficou definido que o relatório “conterá os nomes das partes, a suma do pedido e da resposta do réu, bem como o registro das principais ocorrências havidas no andamento do processo". Como se pode perceber, ao texto foi adicionada a necessidade de referência não só aos elementos subjetivos e objetivos da demanda, mas também a outros acontecimentos do processo que o juiz repute relevantes.

O CPC/2015, corrigindo a imprecisão conceitual, prescreve que o relatório, a fundamentação e o dispositivo correspondem aos "elementos essenciais da sentença". Sentença, nesse caso, é termo empregado como sinônimo de pronunciamentos judiciais com conteúdo decisório ${ }^{5}$, como a decisão interlocutória, o acórdão, a decisão monocrática e, claro, a própria sentença (arts. 203 e 204 do CPC/2015). Por sua vez, o inciso I do art. 489 define que o relatório "conterá os nomes das partes, a identificação do caso, com a suma do pedido e da contestação, e o registro das principais ocorrências havidas no andamento do processo". O único acréscimo digno de nota é a menção à "identificação do caso", sendo razoável interpretar que essa exigência corresponde à suma das causas de pedir fática e jurídica.

Sobre o tema dos elementos da decisão judicial, ainda são necessárias três observações.

A primeira observação diz respeito à estruturação da sentença. $\mathrm{O}$ modo pelo qual o texto do CPC/2015 é redigido, em três partes sequenciais, pode levar à impressão de que o ato decisório deverá ser estruturado, necessariamente, por um silogismo ${ }^{6}$. Ou seja, uma operação lógica em que, primeiro, é estabelecida uma premissa maior; depois, uma premissa menor; e, por fim, uma conclusão que deriva das premissas. Essa impressão

\footnotetext{
${ }^{4}$ Cfr., por todos, BARBOSA MOREIRA, José Carlos. O que deve e o que não deve figurar na sentença. Revista da EMERJ, v. 2, n. 8, p. 42-53, 1999, esp. p. 43.

${ }^{5}$ DIDIER JR., Fredie; BRAGA, Paula Sarno; OLIVEIRA, Rafael Alexandria de. Curso de direito processual civil: teoria da prova, direito probatório, decisão, precedente, coisa julgada e tutela provisória. $12^{\mathrm{a}}$ ed. Salvador: JusPodivm, 2016, vol. 2, p. 354.

${ }^{6}$ Ovídio Baptista, por exemplo, dizia que "é, em última análise, esta estrutura silogística, prescrita pelo art. 458 do CPC [de 1973], que todas as sentenças conterão, ou seja, todas elas, independentemente do modo pelo qual o julgador haja formado seu convencimento, deverão expressar-se através dos seguintes elementos estruturais: a) o relatório; b) os fundamentos; c) o dispositivo ou decisão" (BAPTISTA DA SILVA, Ovídio A. Curso de processo civil: processo de conhecimento. $6^{a}$ ed. Rio de Janeiro: Forense, 2002, vol. 1, p. 401).
} 
mostra-se equivocada, por duas razões. A primeira é que o raciocínio judicial não se desenvolve silogisticamente, mas por meio de uma interpretação complexa, dinâmica - e, até mesmo, irracional - de fatos, provas, textos normativos e valores (contexto de descoberta). A segunda é que, mesmo se concebida a hipótese de uma estruturação lógica da decisão (contexto de justificação), o relatório não corresponderia à premissa maior do silogismo, espaço esse que é reservado à indicação de um enunciado normativo (lei, precedente, doutrina etc. $)^{7}$.

A segunda observação refere-se à ordem dos elementos da decisão. Grande parte da doutrina defende que a decisão judicial não precisa observar a ordem topológica apresentada pelo texto legislativo. Nada impediria, por exemplo, que uma sentença viesse estruturada em relatório, dispositivo e fundamentação. De fato, a lei não comina pena de nulidade nessa hipótese; trata-se mais de uma questão de estilo ou técnica de elaboração da sentença. O importante é que o ato seja inteligível ${ }^{8}$. A praxe, contudo, consolidou a confecção das decisões judiciais segundo a ordem estabelecida pela lei.

A terceira observação é sobre a regulamentação do relatório nos diferentes pronunciamentos judiciais. Curioso notar que os dispositivos mencionados servem apenas a uma espécie de pronunciamento judicial: a sentença. Essa constatação é confirmada pela própria localização dos dispositivos na estrutura dos Códigos, pois todos constam do capítulo referente à sentença, que, por sua vez, está dentro do processo conhecimento em primeiro grau de jurisdição.

Não há menção mais detalhada, por exemplo, sobre o objeto ou características do relatório nos julgamentos colegiados. Apenas poucas referências são feitas em dispositivos no contexto do procedimento e julgamento dos processos nos tribunais.

No CPC/1939, o $\S 1^{\circ}$ do art. 874 previa que "exarado o relatório nos autos, serão êstes conclusos ao revisor, que os devolverá em vinte (20) dias, declarando concordar com o relatório, ou retificando-o". O CPC/1973 foi mais incisivo ao prescrever o que deverá conter o relatório no julgamento colegiado, pois, no parágrafo único do art. 549,

\footnotetext{
7 "O relatório não constitui a premissa maior, mas simples reconstituição do percurso do processo" (ASSIS, Araken de. Processo civil brasileiro: parte geral - institutos fundamentais. São Paulo: Revista dos Tribunais, 2015, vol. II, item 1.116).

${ }^{8}$ COSTA, Eduardo José da Fonseca. Comentários ao art. 489. In: Comentários ao Código de Processo Civil. São Paulo: Saraiva, 2016, p. 593.
} 
determinava que "o relator fará nos autos uma exposição dos pontos controvertidos sobre que versar o recurso".

Atualmente, o CPC/2015 parece ter retrocedido ao não tratar do objeto do relatório nos julgamentos colegiados, apenas disse, no art. 931, que “distribuídos, os autos serão imediatamente conclusos ao relator, que, em 30 (trinta) dias, depois de elaborar o voto, restitui-los-á, com relatório, à secretaria”. Posteriormente, no art. 937, prescreve que o relator, na sessão de julgamento, fará uma "exposição da causa" antes de franquear às partes o direito de realizar sustentação oral.

\section{FUNÇõES DO RELATÓRIO}

Independente da espécie de pronunciamento judicial - se decisão interlocutória, sentença ou acórdão - o relatório tem, fundamentalmente, duas funções. Essas funções não são excludentes, pelo contrário, são complementares e se alimentam reciprocamente.

A primeira função exercida pelo relatório é descritiva.

Nesse espaço do ato decisório, o juiz registrará toda "a história relevante do processo" 9 . O objetivo é demonstrar para as partes e para a sociedade em geral que o juiz estudou o processo em que proferirá a decisão e conhece as questões relevantes do caso que foi posto à sua apreciação ${ }^{10}$. Trata-se de uma demonstração, por parte do juiz, de que tem plena consciência acerca dos sujeitos envolvidos no caso; das razões de fato e de direito que deduziram para que a demanda seja julgada procedente ou improcedente; dos pontos controvertidos e das provas produzidas.

Não é necessária uma descrição pormenorizada e detalhada de todas as minúcias ocorridas durante a marcha processual. Não é isso que a lei exige, pois o relatório “deve

\footnotetext{
${ }^{9}$ PONTES DE MIRANDA, Francisco Cavalcanti. Comentários ao Código de Processo Civil. $3^{\mathrm{a}}$ ed. Rio de Janeiro: Forense, 1997, t. 5 (arts. 444 a 475), p. 66.

${ }^{10}$ Neste sentido, cfr. DIDIER JR., Fredie; BRAGA, Paula Sarno; OLIVEIRA, Rafael Alexandria de. Curso de direito processual civil, vol. 2, p. 354; MARINONI, Luiz Guilherme; ARENHART, Sérgio Cruz; MITIDIERO, Daniel. Curso de processo civil: tutela dos direitos mediante procedimento comum. $3^{\mathrm{a}}$ ed. São Paulo: Revista dos Tribunais, 2017 vol. 2, p. 424-425. Fabiano Carvalho ressalta que essa é uma condição ética do relatório (CARVALHO, Fabiano. A função do relatório no julgamento colegiado - manifestação do princípio do contraditório. Revista de Processo, v. 36, n. 198, p. 445-454, ago., 2011). Daniel Neves adverte, porém, que o relatório não é condição necessária para demonstrar que o juiz conhece o caso (NEVES, Daniel Amorim Assumpção. Manual de direito processual civil. $8^{\mathrm{a}}$ ed. Salvador: JusPodivm, 2016, item 23.3.1).
} 
conter todo o necessário e só o necessário" "11. Por isso mesmo é que o conceito de "principais ocorrências havidas no andamento do processo", presente no inciso I do art. 458 do CPC/2015, deve ser corretamente interpretado como aquelas que tenham relevância concreta para a decisão tomada ao final ${ }^{12}$. O relatório não pode ser elaborado como um "simples índice"13, uma descrição automatizada de tudo o que ocorreu no processo. Deve, em contrapartida, ser um registro contextual dos acontecimentos relevantes para a decisão.

Assim, nas sentenças terminativas ficam dispensadas maiores referências às questões de fato e de direito, ou demais acontecimentos da instrução probatória, sendo suficiente a alusão às ocorrências que conduziram à impossibilidade de julgamento do mérito. Já as sentenças homologatórias não exigem referências às provas ou aos fundamentos de defesa, pois o juiz não se debruçará sobre a procedência ou não destas cabe, ao revés, uma remissão ao pedido e seus fundamentos porque a disposição dos direitos é passível de controle judicial ${ }^{14}$. Nos recursos, não são necessárias referências aos acontecimentos do processo em primeiro grau, apenas aos pontos controvertidos na impugnação.

A segunda função exercida pelo relatório é preparatória.

Ao mesmo tempo em que descreve as ocorrências mais relevantes do processo, o juiz acaba delimitando e planejando a decisão que será tomada. O relatório funciona, portanto, como um ponto da partida da organização do raciocínio que será desenvolvido na fundamentação. Acaba, por assim dizer, "circunstancializando-a, em certa medida"15.

O relatório cumpre um importante papel na delimitação do thema decidendum. Todos os pontos, de fato e de direito, que foram objeto de contraditório, deverão constar do relatório. As partes deduzem pontos de fato e pontos de direito que, uma vez controvertidos, tornam-se duvidosos. Na linguagem de Carnelutti, pontos duvidosos

\footnotetext{
${ }^{11}$ BARBOSA MOREIRA, José Carlos. O que deve e o que não deve figurar na sentença. Revista da EMERJ, p. 45.

${ }^{12}$ FONSECA, João Francisco Naves da. Comentários ao art. 489. In: Comentários ao Código de Processo Civil. São Paulo: Saraiva, 2017, vol. IX, p. 51.

${ }^{13}$ GRECO, Leonardo. Instituições de processo civil: processo de conhecimento. $3^{\mathrm{a}}$ ed. Forense: Rio de Janeiro, 2015, vol. II, p. 295.

${ }^{14}$ Os exemplos das sentenças terminativas e homologatórias foram extraídos de DINAMARCO, Cândido Rangel. Instituições de direito processual civil. $7^{\mathrm{a}}$ ed. São Paulo, Malheiros, 2017, vol. III, p. 769.

15 ARRUDA ALVIM, Teresa. Omissão judicial e embargos de declaração. São Paulo: Revista dos Tribunais: 2005, p. 349.
} 
equivalem a questões ${ }^{16}$. Essas questões deverão ser objeto de cognição na decisão judicial. Em resumo, será o relatório o elemento que "demarcará o que será discutido e resolvido pela sentença" ${ }^{17}$, definindo, assim, a "matéria-prima" da fundamentação ${ }^{18}$.

Diante dessas considerações, não é possível dizer que o relatório é um elemento dispensável da decisão judicial ${ }^{19}$. De elemento que vinha sendo paulatinamente menosprezado ${ }^{20}$, o relatório tem função essencial à descrição e preparação da decisão judicial.

Parcela da doutrina concebe ainda outra função ao relatório. Diante de um sistema que atribui eficácia vinculante aos precedentes judiciais também seria função do relatório aferir a suficiência do contraditório na formação desses precedentes ${ }^{21}$. Além disso, $e$ principalmente, o relatório permitiria a identificação dos fatos relevantes para operacionalizar a aplicação dos precedentes, com identificação dos seus fundamentos determinantes (ratio decidendi), ou, ainda, permitir a aplicação da técnica de distinção (distinguishing). Isso porque é a similaridade entre os fatos, com devida universalização, que permite estender ou não a ratio decidendi do precedente ao caso em julgamento, afinal, é um princípio básico de administração do sistema de justiça que "casos iguais devem ser tratados de maneira igual" 22 .

A doutrina atentou-se para o ponto, originalmente, por ocasião da dispensa do relatório em sentenças proferidas nos Juizados Especiais (art. 38, Lei n. ${ }^{0}$ 9.099/1995) ${ }^{23}$. Buscava-se chamar a atenção para uma função externa do relatório, em que a descrição dos

\footnotetext{
16 CARNELUTTI, Francesco. Sistema de direito processual civil. Trad. Hiltomar Martins Oliveira. São Paulo: Classic Book, 2000, vol. 2, p. 39.

17 BUENO, Cássio Scarpinella. Curso sistematizado de direito processual civil: procedimento comum, processo nos tribunais e recursos. $8^{\text {a }}$ ed. São Paulo, Saraiva, 2019, vol. 2, p. 321.

18 TALAMINI, Eduardo; WAMBIER, Luiz Rodrigues. Curso avançado de processo civil: cognição jurisdicional (processo comum e de conhecimento) e tutela provisória. $18^{\mathrm{a}}$ ed. São Paulo: Revista dos Tribunais, 2019, p. 445.

${ }^{19}$ Neste sentido, defendendo que o magistrado pode avaliar, no caso concreto, a essencialidade do relatório, cfr. CARTAXO, Azevedo Hamilton; CRUZ, Luana Pedrosa de Figueiredo. A efetividade da prestação da tutela jurisdicional e a possibilidade de dispensa do relatório da sentença, em face do inciso LXXVIII, da CF/88. Revista de Processo, v. 33, n. 157, p. 198-208, mar., 2008.

${ }^{20}$ Conforme diagnóstico de DIDIER JR., Fredie; BRAGA, Paula Sarno; OLIVEIRA, Rafael Alexandria de. Curso de direito processual civil, vol. 2, p. 354.

${ }^{21}$ O que é percebido por MACÊDO, Lucas Buril de. Precedentes judiciais e o direito processual civil. $3^{\mathrm{a}}$ ed. JusPodivm, 2019, p. 391.

${ }^{22}$ A emblemática frase de Cross e Harris é citada, no contexto dessa dimensão do relatório, por MARINONI, Luiz Guilherme; ARENHART, Sérgio Cruz; MITIDIERO, Daniel. Curso de processo civil, vol. 2, p. 425.

23 TAVARES JR., Eraldo Ramos. Juizados Especiais, precedente judicial e a importância do relatório. Revista de Processo, v. 38, n. 222, p. 201-218, ago., 2013.
} 
fatos fosse direcionada não só aos sujeitos integrantes daquela relação jurídica processual (aqui, a sua função interna), mas também àqueles que pudessem estar futuramente vinculados ao caso em julgamento. Como esses sujeitos dependeriam da análise dos fatos relacionados ao precedente para identificar a ratio decidendi, o relatório seria essencial para o cumprimento desse escopo.

De fato, a questão merece uma renovada atenção diante do modelo de precedentes incorporado pelo CPC/2015 (arts. 489, § 1º, V e VI, 926 e 927) ${ }^{24}$. É importante analisar a função do relatório não só em relação ao discurso do caso, mas também compreender o seu alcance quanto ao discurso do precedente $e^{25}$.

Apesar disso, parece haver, nesse ponto, uma sobrevalorização do relatório cuja função é apenas de auxiliar na identificação da ratio decidendi. O relatório não tem a capacidade de, sozinho, permitir a identificação dos fatos substanciais. Trata-se de tarefa que compete, precipuamente, à fundamentação da decisão ${ }^{26}$. Confunde-se relatório com exposição dos fatos, sendo que essa pode e deve constar da fundamentação. O relatório, portanto, não exerce uma função determinante, mas apenas secundária em relação aos precedentes judiciais.

A bem da verdade, essa terceira função do relatório defendida por parcela da doutrina consiste apenas em uma consequência das funções anteriormente mencionadas. $\mathrm{O}$ juiz do caso, ao elaborar o relatório, não descreve minuciosamente os fatos essenciais da demanda pensando na aplicação futura de precedentes judiciais, tarefa essa que, inclusive, não lhe compete. O seu objetivo é descrever os acontecimentos mais relevantes e preparar o julgamento daquele caso concreto.

Ainda que o relatório desempenhe uma função auxiliar nesse ponto, se eventual ausência ou defeitos na elaboração do relatório impedirem ou dificultarem a adequada

\footnotetext{
${ }^{24}$ Defendendo essa nova dimensão do relatório à luz do sistema de precedentes do CPC/2015, cfr. NUNES, Dierle. Colegialidade corretiva, precedentes e vieses cognitivos. Revista Brasileira de Direito ProcessualRBDPro, v. 23, n. 92, p. 61-81, out./dez., 2015; DIDIER JR., Fredie; BRAGA, Paula Sarno; OLIVEIRA, Rafael Alexandria de. Curso de direito processual civil, vol. 2, p. 355; CUNHA, Leonardo Carneiro da. Comentários ao art. 489. In: Breves Comentários ao Código de Processo Civil. São Paulo: Revista dos Tribunais, 2015, p. 1229; MARINONI, Luiz Guilherme; ARENHART, Sérgio Cruz; MITIDIERO, Daniel. Curso de processo civil, vol. 2, p. 425; FONSECA, João Francisco Naves da. Comentários ao art. 489. In: Comentários ao Código de Processo Civil, vol. IX, p. 52.

${ }^{25}$ Para uma explicação sobre os espaços de atuação do discurso do caso e do discurso do precedente, cfr. MITIDIERO, Daniel. Fundamentação e precedente - dois discursos a partir da decisão judicial. Revista de Processo, v. 37, n. 206, p. 61-78, abr., 2012.

${ }^{26}$ Concordamos, portanto, com a posição de MACÊDO, Lucas Buril de. Precedentes judiciais e o direito processual civil, p. 392.
} 
interpretação e identificação da ratio decidendi, não é o caso de decretar a nulidade da decisão. Como o precedente é sempre aplicado por um juízo posterior, em caso futuro e análogo, não é possível decretar a nulidade da decisão que o formou devido à preclusão. Mais importante: se não é possível identificar moldura fática que integra a ratio decidendi, o caso não é de nulidade da decisão, mas de ineficácia do precedente.

\section{O RELATÓRIO NAS SENTENÇAS}

O relatório consiste em um dos elementos que corporifica a sentença, como se percebe do próprio art. 489, inc. I, do CPC/2015. Assim, o relatório nas sentenças assume uma importância vital em três diferentes perspectivas, aliando as suas funções descritiva e preparatória. São elas: (i) a técnica de elaboração; (ii) a delimitação do objeto da fundamentação; e (iii) a interpretação da sentença.

Primeiro, em relação à técnica de elaboração.

Para que a função descritiva seja atingida com eficiência, o relatório deve primar pela objetividade ${ }^{27}$, sobretudo considerando que um número razoável de ocorrências do processo deverá ser registrado, englobando tanto a fase postulatória, quanto a fase instrutória. O relatório deve evitar a antecipação de quaisquer juízos sobre as questões debatidas nos autos do processo. Dar pistas sobre o que será posteriormente decidido pode levar a uma conclusão precipitada, eivando o ato decisório de contradição. Não é recomendável o emprego adjetivos desnecessários para classificar atos e argumentos das partes, como, por exemplo, dizer que a petição inicial é "confusa" ou que o argumento da contestação é “incoerente". A fundamentação é o espaço destinado a um juízo desta natureza, avaliando a consistência dos argumentos e das condutas das partes.

O relatório deve ser uma "narração fiel do conjunto de fatos" que traduza um "texto narrativo, ao qual são agregadas características de um texto descritivo-objetivo”, redigido por meio de uma "linguagem denotativa" 28 . Ou seja, o relatório deve, na medida do

\footnotetext{
${ }^{27}$ ASSIS, Araken de. Processo civil brasileiro, vol. II, item 1.121

${ }^{28}$ STOLZE, Pablo; VIANA, Salomão. Manual da sentença cível. São Paulo: Saraiva, 2019, p. 271.
} 
possível, ser neutro em relação à descrição dos argumentos, dos fatos processuais e dos principais acontecimentos do processo $^{29}$.

Quando o juiz subordina a elaboração e redação do relatório à solução que considera acertada, é possível, ao menos tendencialmente, que circunstâncias relevantes para o julgamento sejam omitidas na descrição das principais ocorrências do processo. Isso porque, na mente do julgador, somente as questões que levam à conclusão são dignas de registro, para fins de enfrentamento na fundamentação ${ }^{30}$. Se assim ocorrer, acaba sendo o relatório instrumento de confirmation bias, isto é, um viés de confirmação apenas das crenças ou hipóteses inicialmente formuladas.

Segundo, em relação à delimitação do objeto da fundamentação.

$\mathrm{Na}$ sentença, o relatório cumpre importante papel no controle interno (pelo próprio juiz) e no controle externo (pelas partes) sobre o enfrentamento dos argumentos e questões suscitadas no curso do processo. Nessa perspectiva é que a função preparatória do relatório mais fica evidente.

Em primeiro lugar, ao descrever os sujeitos da relação jurídica processual e resumir a causa de pedir e os pedidos formulados, serve o relatório à delimitação dos limites subjetivos e objetivos da demanda ${ }^{31}$. Auxilia, portanto, na observância da regra de congruência (arts. 141 e 492, CPC/2015).

No aspecto subjetivo, é relevante o registro das partes que compõem a demanda no polo ativo e passivo e se, em algum deles, há litisconsórcio; se houve intervenção de

\footnotetext{
${ }^{29}$ Leonardo Schmitz questiona a pretensão de neutralidade do relatório: "será mesmo que essa objetivação do relato não artificializa a construção argumentativa que vai ocorrer posteriormente na fundamentação? Aliás, querer crer que o relatório seria completamente neutro, e a motivação, aí sim, daria algo de jurídico ao que foi relatado, não contribui para a ideia de uma subsunção entre fatos (relatório) e direito (fundamentação)? Não seria ideal que a redação de ambos ocorresse conjuntamente?" (SCHMITZ, Leonard Ziesemer. Fundamentação das decisões judiciais: a crise na construção de respostas no processo civil. São Paulo: Revista dos Tribunais, 2015, p. 236).

${ }^{30} \mathrm{O}$ ponto foi percebido por Egas Moniz de Aragão: "Se o juiz elaborá-lo [o relatório] em conformidade com a conclusão que está idealizada em sua mente, bem poderá acontecer de revelar-se parcial e infiel, pois salientará somente aquilo que contribui para justificar uma determinar solucão, já que concebida (não se sabe desde quando, nem por quê). Ao contrário, se for elaborado com isenção e fidelidade, provavelmente o juiz deparar-se-á em muitos casos com a necessidade, ou conveniência, de modificar o juizo que se lhe afigurava já formado, em vista de aspectos que ao longo da marcha do processo haviam estado à sombra de outros, insuficientemente iluminados, portanto" (ARAGÃO, Egas Dirceu Moniz de. Sentença e coisa julgada, p. 100).

${ }^{31}$ No relatório, a "menção aos nomes das partes possui importância fundamental. Através dessa providência, estará o juiz indicando com precisão os limites subjetivos do julgado". Além disso, sobre os limites objetivos, deve "o juiz indicar a pretensão formulada na petição inicial, bem assim a causa de pedir; e, de outro lado, os pontos que constituem a resposta do réu" (SANTOS, Nelton Agnaldo Moraes dos. A técnica de elaboração da sentença civil. $2^{\mathrm{a}}$ ed. São Paulo: Saraiva, 1997, p. 62-63).
} 
terceiros, especificando a sua modalidade; se o Ministério Público interveio na causa; se houve exclusão de alguma parte por ilegitimidade, dentre outras questões.

No aspecto objetivo, é importante descrever a causa de pedir fática e jurídica e individualizar os pedidos que foram formulados; qual a modalidade de defesa foi apresentada e, se for o caso, as matérias de defesa arguidas, com indicação da respectiva natureza (processual ou de mérito); se houve ampliação objetiva da demanda, com apresentação de reconvenção; se foi deferida ou indeferida tutela provisória ou se ocorreu julgamento parcial de mérito, além de outras remissões se fizerem necessárias.

A narrativa dos fatos é um dos pontos mais relevantes, senão o mais relevante, do relatório. Afinal, o juiz não conhece os fatos, pois cabe às partes aportá-los no processo, e tampouco tem conhecimento da história por detrás do litígio. Por conta disso, é importante descrever no relatório a sequência cronológica de fatos ocorridos dentro dos autos para uma compreensão segura dos acontecimentos, bem como selecionar, dentre os fatos principais e os fatos secundários, aqueles que são verdadeiramente importantes para a resolução da controvérsia ${ }^{32}$.

Em segundo lugar, o relatório também desempenha relevante função quanto à individualização dos argumentos que devem ser enfrentados. Como se sabe, o art. 489, § $1^{\circ}$, inc. IV, CPC/2015 estabelece um dever de enfrentamento pelo juiz dos argumentos com capacidade de, em tese, influenciar o resultado. Trata-se de uma necessária imbricação entre o contraditório e dever de fundamentação das decisões judiciais. Ao indicar no relatório quais foram argumentos deduzidos no processo, juiz e partes poderão checar se todos eles foram, de fato, analisados.

Em terceiro lugar, o relatório da sentença pode auxiliar no controle da fundamentação em relação ao exame da matéria fático-probatória. Ao historiar a suma do pedido e da defesa, a sentença delimita quais foram os fatos controvertidos no processo, expondo um dos aspectos centrais do problema probatório, que é o objeto da prova ${ }^{33}$. Ademais, ao individualizar quais foram os meios de prova admitidos e quais foram

\footnotetext{
${ }^{32}$ Sobre os dois pontos, cfr. STOLZE, Pablo; VIANA, Salomão. Manual da sentença cível, p. 272 e 274.

${ }^{33}$ Como já alertava Moacyr Amaral Santos sobre o espaço dedicado à prova no relatório ao tempo do CPC/1939, cfr. SANTOS, Moacyr Amaral. Prova judiciária no cível e comercial. $2^{\mathrm{a}}$ ed. São Paulo: Max Limonad, 1952, vol. 1, p. 394.
} 
efetivamente produzidos ${ }^{34}$, bem como ao indicar como foram distribuídas as regras do ônus da prova, o relatório contribui como um guia para que juiz e partes verifiquem se houve enfrentamento de todas as provas relevantes ${ }^{35}$.

Terceiro, em relação à interpretação da sentença.

A sentença deve ser interpretada adequadamente para que os seus destinatários identifiquem o sentido da decisão tomada e possam identificar a norma jurídica individual e concreta produzida para resolução da controvérsia. Por conta disso, a lei processual prevê determinados postulados hermenêuticos para definir como deve ser interpretada a sentença. É nesse contexto que o art. 489, § $3^{\circ}$, do CPC/2015 estabelece que a sentença deve ser interpretada "a partir da conjugação de todos os seus elementos", no que a doutrina chama de postulado da unidade da interpretação da sentença ${ }^{36}$.

O dispositivo fala em "todos os seus elementos", de modo que não só a fundamentação e o dispositivo devem ser interpretados conjuntamente para atribuir sentido ao que foi decidido na sentença, como é mais comum ver indicado na jurisprudência ${ }^{37}$. $\mathrm{O}$ relatório também pode funcionar como um importante referencial na interpretação da sentença $^{38}$. Eventuais signos usados pelo juiz na fundamentação e no dispositivo podem encontrar seu significado à luz da descrição dos fatos e dos principais acontecimentos do processo que estão registrados no relatório.

As considerações acima demonstram que o relatório é verdadeira manifestação do modelo cooperativo de processo, imposto pelo art. $6^{\circ}$ do $\mathrm{CPC} / 2015$, pois estabelece um

\footnotetext{
${ }^{34}$ Marinoni e Arenhart defendem que "pouca coisa pode interessar mais ao relatório do que a definição dos fatos controvertidos e das provas admitidas e produzidas" e lembram que "a relação entre as provas admitidas e as produzidas é importante para destacar a razão pela qual a parte, apesar de ter a prova admitida, não a produziu, e qual o significado que daí pode se extrair" (MARINONI, Luiz Gulherme; ARENHART, Sérgio Cruz. Prova e convicção. $3^{\mathrm{a}}$ ed. São Paulo: Revista dos Tribunais, 2015, p. 317).

35 Também não são consideradas fundamentadas as decisões que não enfrentam todas as provas que, em tese, podem influenciar o julgamento (perspectiva quantitativa) e também as decisões que não valoram todas essas provas (perspectiva qualitativa), como defendemos em PEREIRA, Carlos Frederico Bastos. Fundamentação das decisões judiciais: o controle da interpretação dos fatos e do direito no processo civil. São Paulo: Revista dos Tribunais, 2019, itens 6.1. e 6.2.

${ }^{36}$ MARINONI, Luiz Guilherme; ARENHART, Sérgio Cruz; MITIDIERO, Daniel. Novo Código de Processo Civil comentado. São Paulo: Revista dos Tribunais, 2015, p. 495.

${ }^{37}$ Por exemplo, o STJ, sem mencionar o relatório, já decidiu que "pra interpretar uma sentença, não basta a leitura de seu dispositivo. O dispositivo deve sintegrado com a fundamentação, que lhe dá o sentido e o alcance" (REsp 818.614/MA, Rel. Ministra Nancy Andrighi, Terceira Turma, julgado em 26/10/2006, DJ 20/11/2006).

${ }^{38}$ Percebendo o ponto, cfr. CUNHA, Leonardo Carneiro da. Comentários ao art. 489. In: Breves Comentários ao Código de Processo Civil, p. 1236; FONSECA, João Francisco Naves da. Comentários ao art. 489. In: Comentários ao Código de Processo Civil, vol. IX, p. 61; TIBURCIO, Antonio Augusto. Interpretação das decisões judiciais: particularidades, critérios e instrumentos. Salvador: JusPodivm, 2018, p. 183.
} 
canal de transparência do ato decisório, auxiliando os sujeitos processuais a identificar vícios de contradição, obscuridade ou omissão e controlá-lo via embargos de declaração.

\section{O RELATÓRIO NOS JULGAMENTOS COLEGIADOS}

No julgamento colegiado, ao contrário das sentenças, o relatório não é parte integrante do próprio ato decisório. Isso porque o acórdão é formado gradativamente, com o relatório sendo elaborado pelo relator em gabinete e lançado nos autos antes do início da sessão de julgamento, conforme previsto no art. 931 do CPC/2015.

Além disso, a descrição do relatório na sentença é diferente da descrição do relatório no julgamento colegiado porque o registro das principais ocorrências fica limitado às questões suscitadas no recurso e combatidas nas contrarrazões, sem envolver os demais acontecimentos do processo em primeira instância. O objetivo é a compreensão da matéria devolvida na impugnação ${ }^{39}$. Por exemplo, se o recorrente impugnou em apelação somente o capítulo da sentença relativo aos honorários advocatícios sucumbenciais, não há necessidade de constar do relatório quaisquer referências aos demais capítulos da sentença.

Por conta dessas características, o relatório no julgamento colegiado possui particularidades e tem a sua relevância percebida em duas dimensões diferentes: (i) a função descritiva colabora para que seja respeitado o dever de advertência em relação a questões de ofício e fatos supervenientes; e (ii) a função preparatória contribui para a organização e eficiência do debate nos Tribunais.

Primeiro, em relação ao dever de advertência.

Como o relatório fica disponível nos autos do processo aguardando a inclusão em pauta para julgamento, as partes e demais interessados poderão consultá-lo e, inclusive, pedir esclarecimentos ou ajustes ${ }^{40}$. Nele constarão as questões levantadas pelas partes em suas razões e contrarrazões recursais, bem como eventuais questões de ofício e fatos

\footnotetext{
39 "Não é indispensável, portanto, reproduzir todas as ocorrências do processo, exceção feita às que sejam necessárias à fixação e à compreensão da matéria devolvida na impugnação" (ASSIS, Araken de. Manual dos recursos. $8^{\text {a }}$ ed. São Paulo: Revista dos Tribunais, 2017, item 32.3).

${ }^{40}$ Como defendido por CARVALHO, Fabiano. A função do relatório no julgamento colegiado. Revista de Processo, 2011; CÂMARA, Alexandre. Relatório influencia na agilidade e qualidade dos julgamentos. Consultor Jurídico, 2016. Disponível em <https://www.conjur.com.br/2016-ago-04/alexandre-camararelatorio-influencia-qualidade-julgamento >. Acesso em 26.06.2021.
} 
supervenientes suscitados pelo relator, permitindo que as partes se manifestem sobre esses pontos nas respectivas sustentações orais.

Trata-se de uma releitura do relatório à luz do princípio do contraditório, funcionando como verdadeiro "instrumento de interação e de comunicação entre o relator, de um lado, e recorrente e recorrido, de outro, a fim de evitar os julgamentos de surpresa" ${ }^{41}$. Essa perspectiva é confirmada pelo próprio art. 933 do CPC/2015 que veda decisões-surpresa no âmbito dos Tribunais, exigindo a manifestação prévia das partes sobre fatos supervenientes e questões de ofício.

Nesses termos, o relatório acaba sendo um espaço de efetivação de importantes normas fundamentais do processo civil brasileiro, como, por exemplo, o contraditório (arts. $9^{\circ}$ e 10, CPC/2015) e também a eficiência (art. 8º CPC/2015), pois evitará a suspensão da sessão de julgamento, o que é exigido quando algum membro do colegiado constatar fato superveniente ou questão de ofício durante a votação (art. 933, § $1^{\circ}$, $\mathrm{CPC} / 2015)$.

Segundo, em relação à organização do debate nos Tribunais.

Lançado antes da sessão de julgamento, o relatório pode direcionar os membros do colegiado ao debate das questões previamente indicadas pelo relatório ${ }^{42}$. Essa prévia organização do debate colegiado é reforçada pelo fato de que a sessão de julgamento iniciará com uma "exposição da causa pelo relator", seguida da concessão da palavra aos advogados para sustentação oral, nos termos do art. 937 do CPC/2015.

Essa "exposição da causa" é justamente a leitura do relatório. O relator poderá contextualizar as circunstâncias fáticas do caso e os pontos controvertidos do recurso, porém, não deve ficar adstrito ao que constou do relatório escrito daquele lançado previamente nos autos, devendo, inclusive, "acrescentar pormenores esclarecedores" e "proceder a retificações ou suprir omissões relevantes"43. Trata-se de um momento

\footnotetext{
${ }^{41}$ SOKAL, Guilherme Jales. O julgamento colegiado nos tribunais: procedimento recursal, colegialidade $e$ garantias fundamentais do processo. Rio de Janeiro: Forense, 2007, p. 207-213. Reiterando esse papel, à luz das normas constantes do CPC/2015, cfr. SOKAL, Guilherme Jales. O papel do relator no julgamento colegiado e o projeto de novo CPC: alguns avanços em prol do contraditório. In: Novas tendências do processo civil: estudos sobre o projeto do novo Código de Processo Civil. Salvador: JusPodivm, 2014, v. 2, p. 645-662.

${ }^{42}$ Função também reconhecida por SOKAL, Guilherme Jales. O julgamento colegiado nos tribunais, p. 205206 e por MACÊDO, Lucas Buril de. Precedentes judiciais e o direito processual civil, p. 391.

${ }^{43}$ Alerta feito por BARBOSA MOREIRA, José Carlos. Comentários ao Código de Processo Civil. $6^{\mathrm{a}}$ ed. Rio de Janeiro: Forense, 1994, vol. 5 (arts. 476 a 565), p. 574.
} 
importante do julgamento, pois os demais integrantes do órgão fracionário poderão pedir esclarecimentos ao relator e os advogados das partes poderão, inclusive, realizar intervenções para, de maneira cooperativa, contribuir para a elucidação de circunstâncias relevantes para o julgamento.

Nada impede, como é comum ocorrer na prática, que o relator consulte os advogados das partes e os demais integrantes do colegiado para dispensar a leitura do relatório. Mesmo aceita a proposta, o relator deverá, oralmente, contextualizar minimamente o julgamento e os pontos controvertidos do recurso de acordo com os fatos da causa. Barbosa Moreira alertava para uma série de fatores extrajurídicos que influenciam o julgamento colegiado, destacando a importância não só do texto escrito em que consubstanciado o relatório, como também a relevância de outras circunstâncias relacionadas à exposição oral pelo relator ${ }^{44}$.

A organização do debate colegiado serve, à primeira vista, para o julgamento do caso concreto, pois busca contextualizar as circunstâncias fáticas do caso em que está inserido o recurso, bem como identificar os seus pontos controvertidos para submetê-los à apreciação dos demais membros do órgão fracionário. Trata-se de verdadeira conduta cooperativa do relator, decorrente do princípio do contraditório, pois busca "proporcionar verdadeiro debate entre os demais integrantes do órgão colegiado, tornando possível a formação qualitativa do acórdão, a ensejar maior confiança e segurança às partes" ${ }^{\text {45 }}$.

Com isso, o relatório desempenha papel fundamental para evitar que o julgamento colegiado ocorra sem nenhum diálogo entre os votos proferidos por seus membros. Contribui, dessa maneira, para que, em vez de um modelo seriatim de deliberação colegiada no qual "são proferidos votos de maneira autônoma, comparando-se ao final as conclusões de cada um", seja prestigiado um modelo per curiam em que "se elabora um

\footnotetext{
${ }^{44}$ Sobre o tema, vale a transcrição: "Elaborar o relatório, sobretudo em feitos complexos, é tarefa de inexcedível delicadeza. O relatório pode ser completo ou lacunoso, longo ou breve, minucioso ou resumido, bem ou mal-ordenado, cristalino ou obscuro, objetivo ou tendencioso: em qualquer caso, marcará, de uma forma ou de outra, o julgamento. Além do texto escrito, que em geral se lança nos autos, há as características da exposição oral, feita na sessão; e mil aspectos podem aí assumir relevo, da dicção mais ou menos clara do relator à maior ou menor ênfase com que assinale algum tópico. Teoricamente, o relatório nunca deveria prenunciar o voto de quem dele se incumba; na prática, não raro algo transparece, e a influência pode começar a fazer sentir-se desde esse instante" (BARBOSA MOREIRA, José Carlos. Notas sobre alguns fatores extrajurídicos no julgamento colegiado. In: Temas de direito processual: sexta série. São Paulo: Saraiva, 1997, p. 145-172, esp. p. 165).

${ }^{45}$ CARVALHO, Fabiano. A função do relatório no julgamento colegiado. Revista de Processo, 2011.
} 
acórdão que aponta as conclusões do colegiado sobre cada uma das questões enfrentadas e resolvidas no julgamento" 46 .

Além de todas essas questões, é possível apontar três outras frentes em que o relatório pode contribuir.

No sistema de precedentes, como já referido, a função descritiva do relatório pode funcionar como "uma importante ferramenta em prol da colegialidade e da melhoria das decisões, de modo a se viabilizar a extração de fundamentos determinantes" ${ }^{\text {47 }}$. Embora não seja fundamental para tanto, como já mencionado antes, o relatório poderá auxiliar na compreensão da ratio decidendi a ser extraída caso atribuída eficácia vinculante àquele julgamento para aplicação em casos futuros e análogos, notadamente diante da exposição e contextualização dos fatos essenciais para formação do precedente (material facts) ${ }^{48}$.

No microssistema de formação concentrada de precedentes (IRDR, IAC e Julgamento de Recursos Especiais e Extraordinários Repetitivos), ao mesmo tempo em que o relatório serve como uma prova de democratização da participação de interessados (função descritiva), é capaz de indicar todos os argumentos que deverão ser enfrentados para formação da tese (função preparatória). Inclusive, é neste sentido que deve ser compreendido o art. 984, inc. I, do CPC/2015, aplicável não só ao IRDR, quando prevê que o julgamento iniciará com uma "exposição do objeto do incidente" pelo relator, ou seja, com a leitura do relatório. Fredie Didier Jr. e Leonardo Carneiro destacam que o relatório do acórdão proferido em julgamento de casos repetitivos deve ser o mais minucioso e completo possível. O objetivo é fazer constar "uma espécie de lista, sumário

\footnotetext{
${ }^{46}$ Como defendido por CÂMARA, Alexandre. Relatório influencia na agilidade e qualidade dos julgamentos. Consultor Jurídico, 2016. Sobre modelos de deliberação colegiada, cfr., amplamente, MARINONI, Luiz Guilherme. Julgamento nas Cortes Supremas: precedente e decisão do recurso diante do novo CPC. São Paulo: Revista dos Tribunais, 2015.

${ }^{47}$ NUNES, Dierle. Colegialidade corretiva, precedentes e vieses cognitivos. Revista Brasileira de Direito Processual-RBDPro, v. 23, n. 92, p. 61-81, out./dez., 2015, esp. p. 70.

${ }^{48}$ Sobre o tema, são válidas as lições de Marinoni, ainda que não contextualizadas com a função do relatório, de que "expressar a interpretação, negligenciando-se o delineamento da moldura fática do caso, elimina a possibilidade de se raciocinar com base em precedentes, ou melhor, a possibilidade de se racionalizar a operação com precedentes diante de casos futuros, que, obviamente, serão marcados por fatos cuja dessemelhança terá maior ou menor significado" (MARINONI, Luiz Guilherme. Julgamento nas Cortes Supremas: precedente e decisão do recurso diante do novo CPC, p. 101).
} 
ou índice de todos os argumentos contrários e favoráveis à tese jurídica discutida, examinada pelo tribunal", funcionando como um verdadeiro "guia de consulta" 49 .

$\mathrm{Na}$ interposição do recurso especial fundado em interpretação divergente da lei federal em relação a outro tribunal (art. 105, inc. III, “c”, da CF/1988), a função descritiva do relatório é essencial para demonstrar o chamado dissídio jurisprudencial ${ }^{50}$. Nessa específica hipótese de cabimento, o art. 1.029, § $1^{\mathrm{o}}$ do CPC/2015 exige que o recorrente comprove a interpretação divergente entre os tribunais, dada a um dispositivo da lei infraconstitucional, mediante demonstração das circunstâncias fáticas que identifiquem ou assemelhem os casos confrontados. Para atingir esse objetivo, o STJ considera insuficiente a mera transcrição de ementas para demonstrar a divergência na interpretação, sendo indispensável que o recorrente faça um cotejo analítico entre o acórdão recorrido e o acórdão paradigma mediante transcrição de trechos dos relatórios e dos votos dos acórdãos $\operatorname{confrontados}^{51}$.

\section{EMBARGOS DE DECLARAÇÃO COMO MEIO DE CONTROLE DO RELATÓRIO}

Em regra, o relatório não possui conteúdo decisório porque contém apenas um registro das principais ocorrências do processo. Embora importante para contextualizar o caso concreto e preparar a decisão que será tomada, no relatório não constam decisões sobre a consistência dos argumentos das partes, o peso das provas ou a procedência de pedidos formulados.

Isso não quer dizer, porém, que o relatório não pode ser aperfeiçoado para permitir uma melhor compreensão da fundamentação e do dispositivo. E o aperfeiçoamento do

\footnotetext{
${ }^{49}$ DIDIER JR., Fredie; CUNHA, Leonardo Carneiro da. Curso de direito processual civil: meios de impugnação às decisões judiciais e processo nos tribunais. 14ª ed. Salvador: JusPodivm, 2017, vol. 3, p. 707-708.

${ }^{50}$ Ponto percebido por CARVALHO, Fabiano. A função do relatório no julgamento colegiado. Revista de Processo, 2011.

51 Cfr., por todos, AgInt no REsp 1870646/SP, Rel. Ministro Marco Aurélio Bellizze, Terceira Turma, julgado em 18/05/2021, DJe 21/05/2021; AgInt no REsp 1903321/PR, Rel. Ministro Herman Benjamin, Segunda Turma, julgado em 08/03/2021, DJe 16/03/2021; AgInt no REsp 1899102/DF, Rel. Ministro Herman Benjamin, Segunda Turma, julgado em 08/03/2021, DJe 16/03/2021; AgInt no AREsp 1568037/SP, Rel. Ministro luis felipe salomão, quarta turma, julgado em 04/05/2020, DJe 12/05/2020; AREsp 1578318/SP, Rel. Ministro Herman Benjamin, Segunda Turma, julgado em 10/12/2019, DJe 19/12/2019; REsp 1726191/RS.
} 
relatório pode ser feito por meio de embargos de declaração, quando constatadas omissões, obscuridades, contradições e erros materiais na sua elaboração (art. 1.022, CPC/2015) ${ }^{52}$.

A jurisprudência do $\mathrm{STJ}^{53}$ e do $\mathrm{STF}^{54}$ tem aceitado, sem maiores contraposições, o cabimento de embargos de declaração para sanar erros materiais constantes do relatório. Uma vez que o erro material não consiste em equívoco referente ao conteúdo do julgamento, mas um equívoco manifesto e objetivo que está relacionado à forma de expressão desse julgamento ${ }^{55}$, a correção de eventuais erros materiais do relatório por meio

${ }^{52}$ Neste sentido, vale destacar que "qualquer trecho do pronunciamento judicial pode estar eivado por omissão, obscuridade, contradição ou erro. Desde a parcela do pronunciamento em que o juiz identifica o caso e relata acontecimentos pretéritos até a parcela destinada à efetiva solução de questões, passando pela motivação do ato decisório, o magistrado pode cometer algum deslize ou deixar de contemplar algo que não podia ter deixado de lado. Por isso, admitem-se embargos de declaração endereçados tanto ao relatório quanto aos fundamentos e ao dispositivo de uma decisão a fim de que se zele pela sua ampla perfeição. Afinal, mesmo imperfeições no relatório podem comprometer a correta compreensão do julgado" (BONDIOLI, Luis Guilherme Aidar. Comentários ao art. 1.022, In: Comentários ao Código de processo civil. São Paulo: Saraiva, 2017, vol. XX (arts. 994 a 1.044), p. 160)

${ }^{53}$ Por exemplo, o STJ já acolheu embargos de declaração (i) para "corrigir erro material constante do relatório, mais especificamente quanto ao posto militar cuja promoção intenta alcançar o recorrente, qual seja, o de Coronel PM e não o de Major PM" (EDcl no AgInt no RE nos EDcl no AgInt no RMS 53.280/PI, Rel. Ministro Jorge Mussi, Corte Especial, julgado em 01/12/2020); (ii) para "correção do nome da operadora no relatório do acórdão recorrido" (EDcl no AgInt no REsp 1918853/PR, Rel. Ministro Marco Aurélio Bellizze, Terceira Turma, julgado em 15/06/2021); (iii) entendeu "configurado erro material ao constar, no relatório do acórdão, a existência de despacho saneador" (EDcl no AgInt no AREsp 1573264/SP, Rel. Ministro Antonio Carlos Ferreira, Quarta Turma, julgado em 19/10/2020); (iv) definiu que "o acórdão embargado incidiu em erro material ao registar no relatório questões sem pertinência com o tema versado nos autos, apresentado, pois, conteúdo dissociado do que efetivamente foi sustentado pelo Ministério Público Estadual" (EDcl no AgInt no REsp 1561430/MT, Rel. Ministro Gurgel de Faria, Primeira Turma, julgado em 28/09/2020); (v) por "errônea indicação do recorrente no relatório" (EDcl no REsp 1062787/RJ, Rel. Ministro Arnaldo Esteves Lima, Primeira Turma, julgado em 18/12/2012); (vi) porque "ao contrário do que foi afirmado no relatório, a parte ofertou contrarrazões ao recurso especial" (EDcl no REsp 935.072/MT, Rel. Ministro Mauro Campbell Marques, Segunda Turma, julgado em 21/10/2010); e (vii) para "fazer constar 'O Estado do Rio de Janeiro' onde se lê 'O Estado do Tocantins"' (EDcl no RMS 18.310/RJ, Rel. Ministro Arnaldo Esteves Lima, Quinta Turma, julgado em 14/11/2006).

${ }^{54}$ Por exemplo, o STF já acolheu embargos de declaração (i) afirmando que "presente erro material no relatório, de rigor a sua correção (...) de forma que se leia, na decisão embargada 'A defesa apelou para o Tribunal de Justiça do Estado de Minas Gerais"” (HC 153037 AgR-ED, Relator(a): Alexandre De Moraes, Primeira Turma, julgado em 15/06/2018); (ii) para "suprimir nome indevidamente constante do relatório do agravo regimental antecedente e para que passe a constar tão somente o nome do embargante" (Rcl 42510 AgR-ED, Relator(a): Ricardo Lewandowski, Segunda Turma, julgado em 15/03/2021); (iii) considerando que o relatório apontava "matéria diversa da versada nos presentes autos", decidiu que "reconhecido o erro material no relatório dos embargos de declaração no agravo regimental no habeas corpus, os segundos embargos de declaração são acolhidos neste ponto, para integrar o julgado com a retificação tão somente dos termos do relatório, sem efeito modificativo no resultado do julgamento" (HC 170966 AgR-ED-ED, Relator(a): Edson Fachin, Segunda Turma, julgado em 03/05/2021); (iv) decidiu pela "retificação de erro material constatado no relatório do acórdão embargado" para que conste: "ao julgar a apelação defensiva, o Tribunal de Justiça do Estado de São Paulo redimensionou a pena para 11 (onze) anos e 08 (oito) meses de reclusão" (ARE 738904 AgR-ED, Relator(a): Rosa Weber, Primeira Turma, julgado em 13/04/2018).

${ }^{55}$ Neste sentido, cfr. TALAMINI, Eduardo. O erro material no processo civil. Revista Dialética de Direito Processual, n. 30, p. 46-52, set. 2005. 
de embargos de declaração atingem o objetivo desta via recursal que é justamente o de aperfeiçoar o pronunciamento judicial embargado.

Porém, se uma decisão judicial for proferida sem relatório ou se o relatório for omisso, contraditório ou obscuro, quais seriam as consequências jurídicas? Uma análise da jurisprudência do STJ e do STF nos revela que eventual nulidade do pronunciamento decisório só pode ocorrer se houver prejuízo.

Primeiro, a jurisprudência do STJ.

Em 2001, a Terceira Turma do STJ decidiu que, "se é possível aquilatar os fatos e as razões do indeferimento da inicial, afasta-se a alegação de nulidade por ausência de relatório" ${ }^{56}$. No ano seguinte, em 2002, a Terceira Turma do STJ admitiu a figura do relatório per relationem ${ }^{57}$, modalidade em que há simples reprodução de relatório elaborado em outro ato decisório (sentença ou acórdão), em peças processuais das partes ou, até mesmo, em relatórios constantes de outros processos ${ }^{58}$. Em 2003, a Terceira Turma reafirmou o entendimento de que "contendo o relatório da sentença os elementos necessários à compreensão da causa, sem acarretar qualquer prejuízo ao julgamento, amparado em bem lançada fundamentação, não há falar em violação ao art. 458, I, do Código de Processo Civil [de 1973]" ${ }^{, 49}$.A premissa aplicada aos casos em questão é a clássica lição da teoria das nulidades de que não existe nulidade sem prejuízo. Como o ato processual viciado (no caso, a decisão judicial sem relatório) não gerou nenhum prejuízo à consecução de sua finalidade (no caso, a compreensão dos fatos e dos fundamentos da decisão), não haveria motivo para decretar a sua nulidade.

Sobre a utilização do relatório per relationem, algumas questões precisam ser observadas. Nesses casos, é maior a probabilidade de que omissões ou contradições do relatório anterior sejam reproduzidas. Também há necessidade de atualização do relatório consoante o desenvolvimento da marcha processual. Tal qual o processo, que possui uma dimensão particular no tempo e espaço, a decisão judicial também é um evento com

\footnotetext{
${ }^{56}$ STJ, AgRg no AgRg no Ag 344.593/RJ, Rel. Ministra Nancy Andrighi, Terceira Turma, julgado em 30/05/2001, DJ 25/06/2001, p. 177.

57 "Ao adotar relatório feito em decisão anteriormente lançada nos autos, que contém todos os requisitos necessários, a sentença atende ao disposto no art. 485, I, do CPC [de 1973]" (STJ, AgRg no Ag 451.747/SP, Rel. Ministra Nancy Andrighi, Terceira Turma, julgado em 05/09/2002, DJ 28/10/2002, p. 318).

${ }^{58}$ DINAMARCO, Cândido Rangel. Instituições de direito processual civil, vol. III, p. 768; NEVES, Daniel Amorim Assumpção. Manual de direito processual civil, item 23.3.1.

${ }^{59}$ STJ, REsp 409.506/RO, Rel. Ministro Carlos Alberto Menezes Direito, Terceira Turma, julgado em 29/11/2002, DJ 17/02/2003.
} 
história própria ${ }^{60}$. Sendo assim, a responsabilidade pelo segundo relatório sempre será do juiz que proferirá a decisão, sendo indispensável atenção e cautela para não perpetuar deficiências constantes do primeiro relatório ${ }^{61}$.

Mais recentemente, em 2007 e 2008, a Primeira Turma do STJ reconheceu a nulidade de dois acórdãos por falta de relatório, uma de ofício e outra a requerimento da parte recorrente. O fundamento utilizado foi de que "o relatório é requisito essencial e indispensável da sentença e a sua ausência prejudica a análise da controvérsia, suprimindo questões fundamentais para o julgamento do processo" "62. Em ambos os casos, afastando-se do raciocínio de que haveria necessidade de demonstração de prejuízo para decretar a nulidade do ato decisório, o entendimento foi de que o relatório é um dos elementos que constitui forma jurídica essencial à decisão judicial, de modo que a sua ausência gera, ainda que presumidamente, prejuízo às partes ${ }^{63}$.

No contexto do CPC/2015, a Segunda Turma do STJ decidiu que "o art. 489, §1, do CPC/2015 não elenca falhas decisórias referentes a supostas omissões no relatório das decisões judiciais, pois é inerente a ele que apenas a suma dos principais pontos processuais sejam alinhavados" ${ }^{64}$. Nestes termos, parece haver uma inclinação da Corte, majoritariamente, à ideia de que eventual nulidade da decisão por falta ou defeito na elaboração do relatório só ocorrerá se constatado prejuízo.

Diante desse cenário, a posição que deve prevalecer é de que os vícios constantes do relatório, ou a própria ausência de relatório, não gera nulidade da decisão, salvo se demonstrado prejuízo na compreensão do ato decisório e desde que não seja possível a

\footnotetext{
${ }^{60}$ OLIVEIRA, Zulmar Duarte de. Comentários ao art. 489. In: Processo de conhecimento e cumprimento de sentença: comentários ao CPC de 2015. Rio de Janeiro: Forense, 2017, vol. 2, item 2.

${ }^{61}$ Como alerta DINAMARCO, Cândido Rangel. Instituições de direito processual civil, vol. III, p. 768.

${ }^{62}$ STJ, RMS 25.082/RJ, Rel. Ministra Denise Arruda, Primeira Turma, julgado em 21/10/2008, DJe 12/11/2008; STJ, RMS 20.078/RJ, Rel. Ministra Denise Arruda, Primeira Turma, julgado em 23/10/2007, DJ 22/11/2007, p. 186.

${ }^{63}$ Era como a doutrina defendia antes do CPC/2015, cfr., por exemplo, MELO, Luiz Pereira de. Omissão de relatório na sentença. Revista Jurídica, Porto Alegre, n. 70, p. 19-23, abr./jun. 1965; MELO, Luiz Pereira de. Requisitos essenciais da sentença. Revista de Processo, v. 3, n. 11/12, p. 37-44, jul./dez. 1978; ARAGÃO, Egas Dirceu Moniz de. Sentença e coisa julgada, p. 97; ARRUDA ALVIM, Teresa. Omissão judicial e embargos de declaração, p. 349; SANTOS, Nelton Agnaldo Moraes dos. A técnica de elaboração da sentença civil, p. 65; BAPTISTA DA SILVA, Ovídio A. Curso de processo civil, vol. 1, p. 401; CARVALHO, Fabiano. A função do relatório no julgamento colegiado. Revista de Processo, 2011.

${ }^{64}$ STJ, EDcl no REsp 1816822/SP, Rel. Ministro Herman Benjamin, Segunda Turma, julgado em $12 / 11 / 2019$.
} 
convalidação do defeito ${ }^{65}$. Isso decorre basicamente da primazia do julgamento do mérito como norma fundamental do processo civil (art. $\left.4^{\circ}\right)$ e das regras gerais de invalidades que são aplicáveis em todas as situações. Por isso, a nulidade do pronunciamento judicial só deve ser decretada se houver prejuízo.

Segundo, também cabe uma análise da jurisprudência do STF que, em regra, tem analisado casos em processo penal para (i) aceitar o cabimento de embargos de declaração buscando aperfeiçoar os relatórios das decisões; e (ii) reafirmar a ideia de que é necessário prejuízo para decretar a nulidade do ato decisório.

Mais antigamente, a Segunda Turma da Corte já havia decidido que não deve ser anulada sentença proferida em processo penal que omitiu no relatório as alegações da acusação e da defesa, sob o argumento de que a ausências dessas informações não acarretou prejuízo ${ }^{66}$.

Mais recentemente, ainda no processo penal, o Pleno do STF decidiu não haver omissão em relatório em relação a teses de defesa porque "o relatório, por conter um resumo dos pontos considerados relevantes pelo relator, e podendo ser complementado pelo revisor, não precisa transcrever integralmente as peças constantes dos autos" ${ }^{67}$. Além disso, acresceu que "o acórdão refletiu a análise e sopesamento de todas as provas e argumentos, tendo evidenciado as razões que conduziram ao juízo de procedência das acusações".

Por fim, em recente decisão, a Primeira Turma do STF destacou que os embargos de declaração consistem na via adequada para sanar erros constantes do relatório. Foi decidido que é "inadmissível o uso do mandado de segurança com objetivo de sanar suposta omissão ou obscuridade existente no relatório" de uma Ação Direta de Inconstitucionalidade, porque a pretensão "figura claramente dentre as situações que comportam a oposição dos embargos de declaração"68.

\footnotetext{
${ }^{65}$ É como entende a maioria da doutrina no contexto do CPC/2015, cfr., por exemplo, SCHMITZ, Leonard Ziesemer. Fundamentação das decisões judiciais, p. 237; CUNHA, Leonardo Carneiro da. Comentários ao art. 489. In: Breves Comentários ao Código de Processo Civil, p. 1229; NEVES, Daniel Amorim Assumpção. Manual de direito processual civil. $8^{\text {a }}$ ed. Salvador: JusPodivm, 2016, item 23.3.1; FONSECA, João Francisco Naves da. Comentários ao art. 489. In: Comentários ao Código de Processo Civil, vol. IX, p. 51; OLIVEIRA, Zulmar Duarte de. Comentários ao art. 489. In: Processo de conhecimento e cumprimento de sentença: comentários ao CPC de 2015, vol. 2, item 1.3.

${ }^{66}$ STF, RHC 58899, Relator(a): Décio Miranda, Segunda Turma, julgado em 26/05/1981.

${ }^{67}$ STF, AP 470 EDj-décimos quartos, Relator(a): Joaquim Barbosa, Tribunal Pleno, julgado em 05/09/2013.

${ }^{68}$ STF, MS 35894 ED-AgR, Relator(a): Alexandre De Moraes, Primeira Turma, julgado em 12/03/2019.
} 


\section{ConClusões}

Ainda que pouca atenção tenha sido dispensada ao papel do relatório nas sentenças e nos julgamentos colegiados, é evidente a importância desse elemento na construção das decisões judiciais.

$\mathrm{Na}$ sua função descritiva, o relatório registra os principais acontecimentos do processo e por meio dele o juiz mostra para as partes e para a sociedade em geral que estudou o caso prestes a ser decidido; na sua função preparatória, o relatório tem o condão de delimitar e organizar o material que constará da fundamentação. Além disso, o relatório tem um papel importante, embora não fundamental, para o bom funcionamento do sistema de precedentes adotado pelo CPC/2015 porque auxilia na identificação dos fundamentos determinantes.

Nas sentenças, a técnica de elaboração é importante para não antecipar posições da fundamentação, ao mesmo tempo em que serve à delimitação do objeto da fundamentação. Além disso, o relatório é importante vetor na interpretação da sentença cuja compreensão deve levar em consideração todos os seus elementos.

Nos julgamentos colegiados, enquanto a função descritiva do relatório atende o dever de advertência no tocante a questões de ofício e fatos supervenientes, por meio de sua função preparatória o relatório acaba colaborando para a organização e a eficiência do debate realizado no âmbito dos Tribunais.

Não obstante a constatação de vícios na elaboração do relatório conduza à nulidade da decisão só quando houver prejuízo, os embargos de declaração correspondem a um meio adequado para corrigir erros materiais, contradições, obscuridades e omissões na sua elaboração.

A valorização do relatório constitui premissa essencial ao adequado cumprimento de várias normas fundamentais do processo civil brasileiro, como o dever de fundamentação das decisões judiciais e os princípios do contraditório, da cooperação e da eficiência. 


\section{REFERÊNCIAS}

ARAGÃO, Egas Dirceu Moniz de. Sentença e coisa julgada: exegese do Código de Processo Civil (arts. 444 a 475). Rio de Janeiro: Aide, 1992.

ARRUDA ALVIM, Teresa. Omissão judicial e embargos de declaração. São Paulo, Revista dos Tribunais: 2005.

ASSIS, Araken de. Manual dos recursos. $8^{\text {a }}$ ed. São Paulo: Revista dos Tribunais, 2017.

ASSIS, Araken de. Processo civil brasileiro: parte geral - institutos fundamentais. São Paulo: Revista dos Tribunais, 2015, vol. II.

BAPTISTA DA SILVA, Ovídio A. Curso de processo civil: processo de conhecimento. $6^{\mathrm{a}}$ ed. Rio de Janeiro: Forense, 2002, vol. 1.

BARBOSA MOREIRA, José Carlos. Comentários ao Código de Processo Civil. $6^{\mathrm{a}}$ ed. Rio de Janeiro: Forense, 1994, vol. 5 (arts. 476 a 565).

BARBOSA MOREIRA, José Carlos. Conteúdo e efeitos da sentença: variações sobre o tema. In: Temas de direito processual: quarta série. São Paulo: Saraiva, 1989, p. 175-183.

BARBOSA MOREIRA, José Carlos. Notas sobre alguns fatores extrajurídicos no julgamento colegiado. In: Temas de direito processual: sexta série. São Paulo: Saraiva, 1997, p. 145-172.

BARBOSA MOREIRA, José Carlos. O que deve e o que não deve figurar na sentença. Revista da EMERJ, v. 2, n. 8, p. 42-53, 1999.

BONDIOLI, Luis Guilherme Aidar. Comentários ao art. 1.022, In: Comentários ao Código de Processo Civil. São Paulo: Saraiva, 2017, vol. XX (arts. 994 a 1.044).

BUENO, Cássio Scarpinella. Curso sistematizado de direito processual civil: procedimento comum, processo nos tribunais e recursos. $8^{\mathrm{a}}$ ed. São Paulo, Saraiva, 2019, vol. 2.

CARNELUTTI, Francesco. Sistema de direito processual civil. Trad. Hiltomar Martins Oliveira. São Paulo: Classic Book, 2000, vol. 2.

CÂMARA, Alexandre. Relatório influencia na agilidade e qualidade dos julgamentos. Consultor Jurídico, 2016. Disponível em <https://www.conjur.com.br/2016-ago- 
04/alexandre-camara-relatorio-influencia-qualidade-julgamento>. Acesso em 26.06.2021.

CARTAXO, Azevedo Hamilton; CRUZ, Luana Pedrosa de Figueiredo. A efetividade da prestação da tutela jurisdicional e a possibilidade de dispensa do relatório da sentença, em face do inciso LXXVIII, da CF/88. Revista de Processo, v. 33, n. 157, p. 198-208, mar., 2008.

CARVALHO, Fabiano. A função do relatório no julgamento colegiado - manifestação do princípio do contraditório. Revista de Processo, v. 36, n. 198, p. 445-454, ago., 2011.

COSTA, Eduardo José da Fonseca. Comentários ao art. 489. In: ARRUDA ALVIM, Angélica; ASSIS, Araken de; ARRUDA ALVIM, Eduardo; LEITE, George Salomão (coords.). Comentários ao Código de Processo Civil. São Paulo: Saraiva, 2016.

CUNHA, Leonardo Carneiro da. Comentários ao art. 489. In: WAMBIER, Teresa Arruda Alvim; DIDIER JR., Fredie; TALAMINI, Eduardo; DANTAS, Bruno (coords.). Breves Comentários ao Código de Processo Civil. São Paulo: Revista dos Tribunais, 2015.

DIDIER JR., Fredie; BRAGA, Paula Sarno; OLIVEIRA, Rafael Alexandria de. Curso de direito processual civil: teoria da prova, direito probatório, decisão, precedente, coisa julgada e tutela provisória. 12a ed. Salvador: JusPodivm, 2016, vol. 2.

DIDIER JR., Fredie; CUNHA, Leonardo Carneiro da. Curso de direito processual civil: meios de impugnação às decisões judiciais e processo nos tribunais. $14^{\mathrm{a}}$ ed. Salvador: JusPodivm, 2017, vol. 3.

DINAMARCO, Cândido Rangel. Instituições de direito processual civil. $7^{\mathrm{a}}$ ed. São Paulo, Malheiros, 2017, vol. III.

FONSECA, João Francisco Naves da. Comentários ao art. 489. In: GOUVÊA, José Roberto F.; BONDIOLI, Luis Guilherme A.; FONSECA, João Francisco Naves da (coords.). Comentários ao Código de Processo Civil. São Paulo: Saraiva, 2017, vol. IX.

GRECO, Leonardo. Instituições de processo civil: processo de conhecimento. $3^{\mathrm{a}}$ ed. Forense: Rio de Janeiro, 2015, vol. II. 
MACÊDO, Lucas Buril de. Precedentes judiciais e o direito processual civil. $3^{\mathrm{a}}$ ed. JusPodivm, 2019.

MARINONI, Luiz Guilherme. Julgamento nas Cortes Supremas: precedente e decisão do recurso diante do novo CPC. São Paulo: Revista dos Tribunais, 2015.

MARINONI, Luiz Guilherme; ARENHART, Sérgio Cruz; MITIDIERO, Daniel. Curso de processo civil: tutela dos direitos mediante procedimento comum. $3^{\mathrm{a}}$ ed. São Paulo: Revista dos Tribunais, 2017, vol. 2.

MARINONI, Luiz Guilherme; ARENHART, Sérgio Cruz; MITIDIERO, Daniel. Novo Código de Processo Civil comentado. São Paulo: Revista dos Tribunais, 2015.

MARINONI, Luiz Gulherme; ARENHART, Sérgio Cruz. Prova e convicção. $3^{\text {a }}$ ed. São Paulo: Revista dos Tribunais, 2015.

MELO, Luiz Pereira de. Omissão de relatório na sentença. Revista Jurídica, Porto Alegre, n. 70, p. 19-23, abr./jun. 1965.

MELO, Luiz Pereira de. Requisitos essenciais da sentença. Revista de Processo, v. 3, n. 11/12, p. 37-44, jul./dez. 1978.

MITIDIERO, Daniel. Fundamentação e precedente - dois discursos a partir da decisão judicial. Revista de Processo, v. 37, n. 206, p. 61-78, abr., 2012.

NEVES, Daniel Amorim Assumpção. Manual de direito processual civil. $8^{\mathrm{a}}$ ed. Salvador: JusPodivm, 2016.

NUNES, Dierle. Colegialidade corretiva, precedentes e vieses cognitivos. Revista Brasileira de Direito Processual-RBDPro, v. 23, n. 92, p. 61-81, out./dez., 2015.

OLIVEIRA, Zulmar Duarte de. Comentários ao art. 489. In: GAJARDONI, Fernando da Fonseca; DELLORE, Luiz; OLIVEIRA JR.; Zulmar Duarte; ROQUE, André Vasconcelos. Processo de conhecimento e cumprimento de sentença: comentários ao CPC de 2015. Rio de Janeiro: Forense, 2017, vol. 2.

PEREIRA, Carlos Frederico Bastos. Fundamentação das decisões judiciais: o controle da interpretação dos fatos e do direito no processo civil. São Paulo: Revista dos Tribunais, 2019.

PONTES DE MIRANDA, Francisco Cavalcanti. Comentários ao Código de Processo Civil. $3^{\text {a }}$ ed. Rio de Janeiro: Forense, 1997, t. 5 (arts. 444 a 475). 
SANTOS, Moacyr Amaral. Prova judiciária no cível e comercial. 2a ed. São Paulo: Max Limonad, 1952, vol. 1.

SANTOS, Nelton Agnaldo Moraes dos. A técnica de elaboração da sentença civil. $2^{\mathrm{a}}$ ed. São Paulo: Saraiva, 1997.

SCHMITZ, Leonard Ziesemer. Fundamentação das decisões judiciais: a crise na construção de respostas no processo civil. São Paulo: Revista dos Tribunais, 2015.

SOKAL, Guilherme Jales. O julgamento colegiado nos tribunais: procedimento recursal, colegialidade e garantias fundamentais do processo. Rio de Janeiro: Forense, 2012.

SOKAL, Guilherme Jales. O papel do relator no julgamento colegiado e o projeto de novo CPC: alguns avanços em prol do contraditório. In: Novas tendências do processo civil: estudos sobre o projeto do novo Código de Processo Civil. Salvador: JusPodivm, 2014, v. 2, p. 645-662.

STOLZE, Pablo; VIANA, Salomão. Manual da sentença cível. São Paulo: Saraiva, 2019.

TALAMINI, Eduardo. O erro material no processo civil. Revista Dialética de Direito Processual, n. 30, p. 46-52, set. 2005.

TALAMINI, Eduardo; WAMBIER, Luiz Rodrigues. Curso avançado de processo civil: cognição jurisdicional (processo comum e de conhecimento) e tutela provisória. $18^{\text {a }}$ ed. São Paulo: Revista dos Tribunais, 2019.

TAVARES JR., Eraldo Ramos. Juizados Especiais, precedente judicial e a importância do relatório. Revista de Processo, v. 38, n. 222, p. 201-218, ago., 2013.

TIBURCIO, Antonio Augusto. Interpretação das decisões judiciais: particularidades, critérios e instrumentos. Salvador: JusPodivm, 2018. 